\title{
Leading trends and contradictions in bank crediting of the population in Russia
}

\author{
Elena Tarkhanova \\ University of Tyumen \\ Volodarskogo str. 6, 625003 Tyumen \\ Russian Federation \\ e-mail: tarhanova333@mail.ru \\ Oksana Fedorova \\ Industrial University of Tyumen \\ Volodarskogo street 38, 625000 Tyumen \\ Russian Federation \\ e-mail: fob2006@yandex.ru
}

\begin{abstract}
The development of market relations in Russia has led to an increase in consumer activity and has become an important factor in the formation and evolution of the market of bank lending to the population. An increasing number of leading Russian commercial banks are involved in active operations in this segment of the banking sector, so bank lending to the population is one of the most dynamically developing areas of the banking business. The process of developing an effective market for bank lending in Russia in recent years has been multidirectional. The crisis of 2014-2015 revealed the main shortcomings of the current stage of the formation of retail lending activity of commercial banks, which in the long term will allow passing to qualitative growth of this banking sector segment. Negative phenomena in the Russian economy in the last few years caused the problem of further development of the market for bank lending to the population as one of the most important factors for ensuring effective demand of the population.

This paper analyzes the current problems that impede the functioning of the market for bank lending to the population and provides hypotheses about the prospects for its leading development. The conclusion is made about the restoration of this market, but the vector of movement of the basic market statistical indicators cannot be unambiguously determined, since it depends on many factors, including foreign policy, which have a significant impact on the economy of the country.
\end{abstract}

\section{Introduction}

The purpose of this study is to determine the vector of current development and prospects for the market of bank credititng of the population based on an analysis of the main indicators dynamics, as well as the identification of the key factors determining the specifics of this phase of changes in the credit market conditions.

One can see that over the past few years, the Russian economy has been affected by numerous adverse factors, such as a complex political environment, a low price for energy resources, inaccessibility of the European borrowing market for leading Russian banks, and a significant weakening of the national currency. As a result of these determinants, the real sector of the economy in the country is experiencing considerable difficulties, since the main industrial high-tech equipment that is used in Russian enterprises is imported and, consequently, the devaluation of the ruble has led to an increase in the prices of components needed for maintenance. At the same time, there is a decline in the standard of living of the population and disposable income of households, which causes a reduction in effective demand.

Thus, in order to support the real sector of the economy, it is necessary to stabilize the market for bank lending to the population in Russia. It should also be noted that in 2014-2015 there was a toughening of credit conditions, which was due to the increase in the cost of credit resources and the growth of overdue debts. In the scientific literature such a situation is defined as a credit crisis.

\section{Literature Review}

Evaluating the degree of development of the research topic, it should be noted that the theoretical and practical aspects of bank lending to the population are sufficiently covered in the works of many Russian and foreign scientists (see e.g. Zinkevich 2007; Jiroudková et al. 2015; Chamberlin 2015; Paulík et al. 2015; Simionescu et al. 2016; Barth et al. 2017; Amel-Zadeh et al. 2017; Gavurova et al. 2017; Teresienė 2018; or Kunitsyna et al 2018). 
However, despite a $\mathrm{n}$ impressive number of scientific publications devoted to retail lending, the issue of forming and developing the market for bank lending to the population remains insufficiently developed. Many works contain only a few theoretical aspects of lending to the population. Also, in the scientific literature it is difficult to find a unified approach to the systematization of the current problems of the consumer lending market in Russia, to the distinguishing of determinants that have a significant impact on its development (Lukmanova and Mishlanova 2015). Continuous development of economic theory in general and the theory of banking in particular, determines the variety of types, forms and methods of lending to the population.

In order to define the concept of bank lending to the population, a number of methodological principles should be taken into account. Defining the importance of credit as an economic category, it is necessary to remember that the essence of the concept of credit should not depend on the form of its implementation. In the scientific works of different authors, the concepts of forms, types or classes of credits are identified, thus creating a discussion about the correctness of substitution of some concepts by others (see e.g. Anisimova 2014; Rusanov et al. 2015; Baburina et al. 2017).

As a result, we can conclude that bank lending to the population can be carried out in various forms, but the lending object remains the only object - loanable value, which has an unproductive form and whose movement is carried out on the principles of urgency, payability and repayment.

Given the exceptional social importance of lending to the population, it is necessary that this economic process be carried out on the basis of certain and legally fixed principles. Lending to the population is an economic category with an internal essence that manifests itself in its structure, forms and types, but also actively interacts with the external environment, with other spheres of the economy and significantly influences them. This influence and its directions are determined by those functions that the credit performs. The existing contradictions regarding the essence and content of lending to the population and its functions are due to the lack of methodological, basic approaches to its analysis.

\section{Purpose and methods of analysis}

While writing this work, we used such methods of economic research as a systematic approach to the study of the object of research, a graphical method to clearly illustrate the processes taking place in the consumer lending market. On the basis of the scientific approach, the actual material on the topic of the study is examined using the methods of comparison, generalization, economic and statistical information processing.

High rates of growth in the market for bank lending to the population are generally considered to be a positive factor in the country's economic development, but in practice this relationship does not always exist, as according to IMF experts "if the share of loans in GDP grows faster than 5\% a year and is accompanied by the increase in share prices by more than 15\%, the likelihood of a financial crisis is $20 \%$ over the next two years" Lavrushin 2012, p.173).

Our detailed study of the market of bank lending to the population makes it possible to identify three groups of basic determinants of the development direction. An analysis of these determinants allows us to conclude that the emergence of the market of bank lending to the population is conditioned both by the desire of the borrower to obtain a loan, and by the desire of the lender to place his temporarily idle funds and receive a profit in the form of interest. However, both sides of the loan agreement have responsibilities. For example, the primary responsibility of the borrower is the timely servicing and repayment of the loan. Thus, the conscientiousness of compliance by the subjects of credit relations with the totality of their rights and obligations affects the level and degree of the credit market development.

Under modern conditions, the market of bank lending to the population, like any other market, is not spontaneous, but requires state regulation. The state is called upon to protect the legitimate rights and interests of market participants - creditors and borrowers both at the level of legislative normative and direct control of all types of professional activity in this market. Such regulation is typical for all developed countries that have a wide range of laws and legal acts regulating activities in the market of bank lending to the population.

\section{Results and discussions}

In 2014, the cooling period came to the Russian market of retail lending after rapid growth, which lasted for 3 years. The difficulties that arose in the Russian banking sector were caused by external and internal factors. The most significant of them is the adoption of a number of restrictive measures in relation to leading Russian banks due to the aggravation of foreign policy relations. The result of these sanctions was the inaccessibility of lending to Russian banks from the West, i.e. they lost one of the most profitable, from a financial point of view, source of resources (Kovelin and Tarkhanova 2017).

The share of consumer lending in the market of bank crediting in Russia did not exceed 20\% and had a negative dynamic over the past few years. The trend of decreasing the share of lending to the population in the total volume of this market is explained by the fact that the real disposable incomes of the population of Russia 
are declining for 3 years and there is an increase in the propensity of citizens to save, which leads to a slowdown in issueing new loans and a decrease in this indicator both in absolute and in relative terms.

The total debt of the population on bank loans for 2016 increased by $2.4 \%$ (for the same period in 2015, a decrease of $5.8 \%$ was recorded) and amounted to 10.6 trillion rubles, which is $12.4 \%$ of Russia's GDP. In economically developed countries, the value of this indicator reaches 50-80\% of GDP. According to the target long-term level established by the Ministry of Economic Development of the Russian Federation (2018), the ratio of household loans to GDP should be at the level of $54 \%$ by 2030 . The impact of all these factors on the dynamics of indicators for loans in rubles provided to the population in Russia, is shown in Table 1.

Table 1. Dynamics of the indicators of bank crediting of the population in Russia, in rubles, mln rubles.

\begin{tabular}{|l|c|c|c|c|c|}
\hline Indicators & $\mathbf{2 0 1 2}$ & $\mathbf{2 0 1 3}$ & $\mathbf{2 0 1 4}$ & $\mathbf{2 0 1 5}$ & $\mathbf{2 0 1 6}$ \\
\hline $\begin{array}{l}\text { The volume of loans provided } \\
\text { to the population }\end{array}$ & 7075352 & 8612537 & 8461421 & 5765755 & 7100623 \\
\hline Rate of increase, \% & - & 21,7 & $-1,8$ & $-31,8$ & 23,2 \\
\hline $\begin{array}{l}\text { Debt for loans granted to the } \\
\text { population: }\end{array}$ & 7474221 & 9698947 & 11005284 & 10366829 & 10619209 \\
\hline Rate of increase, \% & - & 29,8 & 13,5 & $-5,8$ & 2,4 \\
\hline -including overdue & 276927 & 406452 & 620287 & 802661 & 810127 \\
\hline Rate of increase, \% & - & 46,8 & 52,6 & 29,4 & 0,9 \\
\hline
\end{tabular}

Source: Own results

According to the Table 1, a number of observations can be made: first, retail lending indicators in rubles until 2014 showed a positive trend (growth rates of more than 20\%), 2015 is characterized by the manifestation of the greatest crisis phenomena, which in turn affected the dynamics of the consumer lending market that became negative $(-31.8 \%)$. Second, the data for the results of 2016 indicate the stabilization of the situation in the banking sector and, as a result, the restoration of the growth rates of key indicators. To understand the trends in the development of the market for bank lending in Russia at the federal level, it is necessary to consider the factors that led to this development in the retail lending segment (Central Bank of Russia 2016a).

Negative changes in the dynamics of the indicators of bank lending to the population began to appear in 2014. One of them is the discrepancy between the volume of loans granted and the growth rate of debt on loans, i.e. most of the newly issued loans were directed to refinance the existing debts. In 2016, individuals were granted loans in the aggregate amount of 7.1 trillion rubles, at the same time, net debt increased by only 0.2 trillion - up to 10.6 trillion rubles. Thus, $97 \%$ of the volume of loans granted to the population during the whole year of 2016 was aimed at refinancing existing debts. While in 2014 this indicator was at the level of $84 \%$ Central Bank of Russia 2016).

The aggregate credit debt of the population to banks as of January 1, 2017 was 10.6 trillion rubles. The amount of debt for each citizen of the Russian Federation exceeds 73.5 thousand rubles. According to Rosstat's statistical data, the average per capita monetary income in Russia does not exceed 31 thousand rubles, so it can be calculated that every Russian, including disabled citizens, owes to banks an average of 2.4 monthly salaries (National Credit Bureau 2016).

Table 2. Dynamics of indicators of bank lending to the population in Russia, in foreign currency, million rubles

\begin{tabular}{|l|c|c|c|c|c|}
\hline Indicators & 2012 & 2013 & 2014 & 2015 & 2016 \\
\hline $\begin{array}{l}\text { The volume of loans provided } \\
\text { to the population }\end{array}$ & 151071 & 165626 & 168301 & 95586 & 109659 \\
\hline Rate of increase, \% & - & 9,6 & 1,6 & $-43,2$ & 14,7 \\
\hline $\begin{array}{l}\text { Debt for loans provided to the } \\
\text { population }\end{array}$ & 237410 & 226975 & 289482 & 267 & 154524 \\
\hline Rate of increase, \% & - & $-4,4$ & 27,5 & $-7,6$ & $-42,2$ \\
\hline -including overdue & 35581 & 32709 & 45356 & 58766 & 46011 \\
\hline Rate of increase, \% & - & $-8,1$ & 38,7 & 29,6 & $-21,7$ \\
\hline
\end{tabular}

The level of the indebtedness of the population of the Russian Federation to credit institutions is at a high level, but it can not be called critical. The absolute value of the debt of the population of Russia is not a negative factor, since the structure of credit debts of citizens, significantly different from that in developed countries, is more significant for understanding the trends in the development of retail lending. For example, in the countries 
of the European Union and the United States, mortgage lending predominates, characterized by long maturities, as well as low interest rates, which makes this type of lending dominant in the debt structure. For Russia, the reverse situation is typical, characterized by the predominance of short-term consumer loans (about $48 \%$ of the aggregate debt according to Rosstat - Russian Federal State Statistics Service), which are issued at high interest rates (Central Bank of Russia 2018). There are similar trends in the dynamics of the main indicators for loans granted to the population in Russia in foreign currency, which is presented in Table 2 above.

For example, until 2014, there was a gradual increase in loans issued, which did not exceed $10 \%$. More important for the study is the debt indicator for foreign currency loans. Until 2014 negative growth rates prevailed, but in 2014 there was a significant increase in debt (by 27.5\%), which is associated with significant volatility of the national currency. The devaluation of the ruble against the U.S. dollar in January 2015 reached $87 \%$ compared to the rate in July 2014. At the end of 2015, the population's debt on foreign currency loans declined by $7.6 \%$, despite the fact that the U.S. dollar exchange rate for December 2011-January 2016, which was the base for calculation, exceeded 70 rubles. Negative dynamics of the indebtedness indicator, typical for 2015, is primarily the result of a significant reduction in loans issued to the population in foreign currency following the results of this time interval, which exceeded $43 \%$. It is also necessary to pay attention to the fact that a mortgage has the largest share in the structure of the hard currency debt of the population in Russia, which is characterized by high monthly payments, increased by 2-2.5 times due to the devaluation of the ruble. This situation led to a trend of a significant increase in overdue debt by $38.7 \%$ and $29.6 \%$ in 2014-2015, respectively (Central Bank of Russia 2018).

At the beginning of 2015, the credit policy of Russian banks was dominated by the tendency to minimize credit risks, which led to an increase in rates for major credit products and, consequently, to a decrease in the volume of new retail loans. The market for bank lending was expecting the decision of the Central Bank of Russia (CBR) on a key rate, which began to decline since February 2015. The result of the CBR's actions was the beginning of a partial restoration of the banking sector, which was fixed in mid-2015, but it is possible to expect the loan volumes and the quality of the loan portfolio to reach the pre-crisis level only if the subjects of the economy adapt to the new macroeconomic situation. The most significant factor stabilizing the situation in the banking sector was the reduction of the key rate by the Bank of Russia to $11 \%$ in August 2015 .

The development of the market of bank crediting of the population occurs under the influence of numerous determinants, which include such indicators as the level of domestic consumption and inflation. At the end of 2015 , inflation was fixed at the level of $12.9 \%$ (according to Rosstat), which does not contribute to the recovery of the lending market. The factors that hampered the growth of retail lending also include denial of access to Russian banks for European markets of cheap loans and tougher conditions for issuing new loans to the population. In addition, since July 2015, the CBR has set limits on the full cost of loans, which have limited the ability of banks to compensate losses from issuing risky loans by raising rates. As a result, the share of approved loan applications decreased by 3 times in 2015, compared to the same indicator at the beginning of 2012. According to the CBR forecast, a full-fledged restoration of the market for bank lending to the population will become possible only with a decrease in the inflation rate to a level of 7-8\%. It is worth noting that by the end of 2016 Rosstat confirmed inflation at $5.4 \%$, which is a positive impetus for the development of the banking sector (Federal Statistics 2018).

An important indicator in analyzing the condition of the market for bank lending is the level of overdue debt, which determines the quality of loan portfolios, the efficiency and riskiness of the activities of credit institutions. Most of the Russian banks before the crisis of 2014 actively carried out high-risk lending to the population in various forms (car loans, mortgages, consumer loans, POS loans). This trend led to the fact that the volume of credit portfolios of credit institutions increased significantly, but their quality was steadily declining. A significant part of Russian commercial banks has not yet developed a single mechanism for evaluating potential borrowers that would allow a simple assessment of the maximum loan amount. In addition, there are still difficulties related to the lack of a common base of customers with outstanding loans and late payments, which may allow the screening of such applications at the review stage. The main direction of improving the activities of Russian banks should be the development of the necessary internal banking regulations, as well as the development of relatively new credit forms, which include, for example, overdraft or credit through plastic cards. Also, an important aspect of this direction is conducting marketing research to determine the needs of the population for new lending options.

Indicators of overdue debts on loans to the population for 2012-2016 are presented in Table 3. In the period 2011-2014 a relatively low share of overdue debt in the total volume of debt on loans to the population remained, which is primarily due to the fact that in the period there was a stable macroeconomic situation and the future expectations of the population were favorable. Thus, individuals were not afraid to use borrowed funds to finance their expenses. In the second half of 2014 and throughout 2015, there was an increase in the share of loans with overdue payments, both in rubles and in foreign currency, to $7.74 \%$ and $21.9 \%$ respectively. The main reason for such dynamics was unfavorable foreign policy events, which caused difficulties in the development of Russian economy. The establishment of such a trend became possible due to unfavorable macroeconomic conditions 
characterized by a significant devaluation of the ruble, instability of prices in the world energy markets, and the economic sanctions of the EU countries on leading Russian banks.

As a result, credit institutions in the Russian Federation were forced to significantly limit the amount of new loans to the population, achieving this goal by raising interest rates. Thus, borrowers who already had several loans were practically unable to refinance their debts using new loans. This situation led to the fact that a significant number of borrowers stopped payments, thereby increasing the share of problem loans. However, beginning of 2016 was marked by the emergence of a tendency to reduce the number of borrowers with several loans, according to the National Bureau of Credit Stories, as of April 1, 2016, their number was 7.65 million. Compared with April 2015 , this indicator was recorded to decline by $28.8 \%$. The main factor that conditioned the possibility of achieving this result was the activity of Russian banks aimed at improving the quality of their own loan portfolios, which was achieved by increasing the effectiveness of risk management methods at various stages of the lending process. The continuation of such a trend in 2016 positively influenced the rates of further recovery of bank lending market to the population (Yusupova 2015).

Table 3. Share of overdue debt in the total amount of debt in bank lending in Russia, 2012-2016, \%

\begin{tabular}{|l|c|c|c|c|c|}
\hline Indicators & 2012 & 2013 & 2014 & 2015 & 2016 \\
\hline $\begin{array}{l}\text { The share of overdue debt in the } \\
\text { total amount of debt on loans to } \\
\text { the population, total: }\end{array}$ & $4,1 \%$ & $4,42 \%$ & $5,89 \%$ & $8,1 \%$ & $7,9 \%$ \\
\hline - for loans in rubles & $3,7 \%$ & $4,2 \%$ & $5,64 \%$ & $7,74 \%$ & $7,6 \%$ \\
\hline - for loans in foreign currency & $15,1 \%$ & $14,4 \%$ & $15,77 \%$ & $21,9 \%$ & $29,77 \%$ \\
\hline
\end{tabular}

Throughout 2016, the trend of a gradual decline in interest rates prevailed, both for short-term and longterm loans. This dynamic, in the first place, was a consequence of the decrease in the Bank of Russia's key rate from $11 \%$ at the beginning of the year to $10 \%$ in September 2016. Lower interest rates on loans to the population contributed to an increase in lending and stabilization of the situation in the banking sector. It should also be noted that the factor of inflationary pressures exerted a negative influence on the population crediting market in 2015, which led to a slowdown in the process of economic recovery. Forecasts for the development of the Russian economy were not unambiguous, but by the end of 2016, Russia's GDP fell by only $0.2 \%$, and inflation did not exceed $5.4 \%$, which undoubtedly positively affect the growth of the lending market.

An important aspect of the analysis of the market for bank lending in Russia is the consideration of the situation in the main segments of this market. Primary value for the population has mortgage housing loans, which is more than $40 \%$ of the total debt on loans. It should be noted that this kind of lending from the position of banks is not the most profitable, since it refers to long-term loans and, as a rule, has lower interest rates, however, according to the Russian statistics, mortgage loans have the lowest share of overdue debt (no more than 2- 3\% in 2017)

According to the Bank of Russia (2016) in 2016, the population's debt on mortgage housing loans to Russian commercial banks reached 4.4 trillion rubles, an increase of $14.8 \%$ compared to 2015 . The similar growth rate of the aggregate portfolio of mortgage loans was in the previous period, while in the period from 2012 to 2014 the increase was generally more than $30 \%$ per year. The volume of loans granted to the population for the purchase of real estate in 2016 increased by $27.2 \%$ and reached the level of 1.472 trillion. In spite of the fact that in 2015 the decline of this indicator was registered by $34 \%$ to 1.157 trillion rubles (Central Bank of Russia 2018).

Analysis of the Bank of Russia (2018) and using the statistical data on the volume of consumer lending allows us to conclude that the share of mortgage housing loans in the aggregate portfolio of household loans in 2016 increased from $20 \%$ to $20.7 \%$. In the framework of mortgage lending in 2016, Russian banks provided the population with 856.4 thousand loans, which is $22.5 \%$ more than in the previous period. The growth in lending for financing the purchase of real estate for 2016 may be due, first, to a favorable conjuncture in the real estate market due to the crisis and a decline in real demand, second, strengthening the ruble's exchange rate against the dollar / euro, third, the expectation of maintaining a low level of inflation in 2017 and subsequent years. The recovery in the growth rates of mortgage market indicators is due to a decrease in interest rates by banks under their own programs, and the extension of state subsidies to interest rates under the Mortgage with State Support program. As the volume of commissioning of new living spaces decreases and the effect of state support weakens, deals with secondary housing are beginning to make an increasingly significant contribution to market volumes. The revitalization of the mortgage market leads to increased competition among private banks.

The volume of overdue debt on mortgage housing loans in 2016 increased by $21.6 \%$ - to 48.05 billion rubles, while in 2015 it was recorded an increase of this indicator by $36.5 \%$. The share of overdue loans in the aggregate portfolio of mortgage housing loans for 2015 and 2016. remains at the level of 1.1\%, which is one of the lowest indicators among other types of loans. 
During 2016, there was a multi-directional dynamic of both the period and the interest rates on mortgage loans. Weighted average interest rates on loans for home purchase decreased from $13.4 \%$ in January 2016 to $12.6 \%$ in December. This trend could be due to numerous factors, however, among the main determinants is the reduction of the Bank of Russia's key rate to $10.5 \%$ in June 2016, as well as the reduction of inflation from $12.9 \%$ in 2015 to $5.4 \%$ in 2016 . The dynamics of the indicator 'weighted average term of mortgage lending' remained relatively stable and exceeded 180 months. It is worth noting that for 8 years the average term of the mortgage loan has not decreased less than 15 years. The reasons are: high inflation rates, which in theory allows the borrower to easily pay monthly payments, due to a decrease in the real value of money; the extension of the loan period allows the borrower to reduce the amount of monthly payments; the low growth rates of the average salary in Russia cause an increase in the average mortgage loan period (RBK 2016).

Another key segment of the consumer lending market is car loans. The unfavorable economic and political events that took place in the Russian economy in 2014 caused uncertainty about the prospects for the development of this segment for the next few years.

The largest decline in this indicator was recorded in 2015, following which the issuing of new car loans decreased by $43.2 \%$. This trend was caused by the devaluation of the ruble, which led to a significant increase in the prices of imported cars, as well as the limited financial possibilities of potential buyers and the instability of the economic situation in the country. However, by the end of 2016, the car loan market grew by $7.6 \%$, which contributes to its stabilization and the beginning of recovery (RAMR 2018).

In 2016, the share of cars that were sold on credit was $46.5 \%$ of the total sales of new cars, according to data provided by the National Bureau of Credit Histories. It should be noted that by the end of 2015 this indicator did not exceed $45 \%$, and by the end of $2014-40 \%$. The increase in the share of cars sold on credit is due to the continuation of the concessional lending state program, the increase in car prices and a decrease in real incomes of the population. In 2015, one of the fastest rates of decline in the car loan market was noted. The main factors that contributed to the emergence of this trend were, first, stricter conditions for borrowers, and high volatility of the ruble, and second, the suspension of the program on preferential car loans, which was renewed on April 1, 2015. The termination of this state program in 2014 directly affected the decrease in the number of cars sold on credit. The car market has been characterized by redistribution of interests of potential buyers in the direction of second-hand cars since the second half of 2014. It is also worth noting that a significant proportion of consumers decided to postpone the purchase of a new car for an indefinite period. The difficult economic situation in the country, which was caused by sanctions and devaluation of the ruble, led to a decline in the standard of living of the majority of Russian citizens who were forced to postpone the purchase of a car until better times. As a result, during the crisis in the car market, significant deferred demand was formed - according to the estimates of the Association 'Russian Automobile Dealers' (ROAD), it has reached 1.3 million vehicles. The possible implementation of this accumulated demand in 2017-2018 is the main factor in the return of pre-crisis volumes of car loans.

In 2016, the share of used cars in Russia, purchased on credit, increased to $20 \%$. In 2015, this indicator was at the level of $15 \%$, and in 2014 did not exceed $10 \%$. This trend is due to several factors that have a cumulative effect for the used equipment market and for the car loan market. First, the used car market is less sensitive to the situation in the economy. Even in difficult economic conditions, when the segment of new cars falls due to a significant increase in prices, the cost of equipment in the secondary market increases not so fast and remains relatively stable. Second, the development of Trade-In programs by official dealers, which help buyers with a car to sell it, has a positive impact on the dynamics of the market indicators. In 2016, the amount of overdue loans with a period of more than 30 days for auto loans increased by $6.7 \%$ (or 6.5 billion rubles in absolute terms) and as of 01.01.2017 exceeded 102.4 billion rubles (as of January 1, 2016 this indicator was at the level of 95.9 billion rubles). It is worth noting that the total amount of indebtedness on current car loans as of 01.01.2017 was 1.02 trillion rubles, declining for the calendar year by 70 billion rubles or by $6.5 \%$ (as of $01.01 .2016-1.09$ trillion rubles). At the same time, the indicator of the share of car loans in the total debt of the population has gradually decreased over the last few years in Russia and amounted 9.6\% as of 01.01.2017 (National Credit Bureau 2016).

In Russia the indicators of the credit card market as well as in other segments demonstrated positive dynamics in 2016. Therefore, in the 4th quarter of 2016, the share of borrowers' credit card limits, which are also called the share of recycling, reached $68.6 \%$, an increase of $8.1 \%$ compared to the previous quarter. However, the average credit limit for credit cards in 2016 was 47.3 thousand rubles, decreased by $15.1 \%$ from the beginning of the year (55.7 thousand rubles in the first quarter of 2016. The largest decrease of the average limit was in the second half of 2016 (National Credit Bureau 2017). Under the conditions of a policy of minimizing risks and improving the quality of the loan portfolio, Russian commercial banks, which are leaders in the credit card market, are forced to make the most efficient use of such parameters of loans as card limits. This allows credit institutions to minimize their own financial losses through rapid and flexible regulation of credit risk. The trend of increasing overdue debt in this segment of consumer lending in 2016 led to a more thorough assessment of potential borrowers by commercial banks. At the same time, the growth rate of the number of issued credit cards and the volume of 
loans issued remained at a relatively high level, the reduction was recorded only in the credit limits, and the share of borrowers' credit card limits (or the share of recycling) also showed a steady growth.

\section{Conclusions}

As a result of the analysis of the current state of the population lending market in Russia, it is possible to draw certain conclusions: first, at the end of 2016 almost all segments of the retail loans market demonstrated steady growth, which was due to stabilization of the foreign policy environment and adaptation to the current economic situation; second, a positive impetus for the increase in lending was the reduction of the key rate by the Bank of Russia to $9.25 \%$; third, the crisis of 2014-2015 positively influenced the further improvement of the mechanisms of the bank lending market of the population, as commercial banks became more responsive to the issues of assessing the creditworthiness of borrowers, which within the medium term positively affect the quality of the loan portfolio.

Prospects for further recovery and development of the market of bank lending to the population in Russia will be determined by the general direction of the development of the macroeconomic situation. However, it should be noted that, while maintaining the current conjuncture of energy prices and exchange rates, the growth of the consumer lending market will continue in 2018 .

\section{References}

Amel-Zadeh A. Barth ME, Landsman WR. (2017) The contribution of bank regulation and fair value accounting to procyclical leverage. Review of Accounting Studies 22(3):1423-1454. doi: 10.1007/s11142-017-9410-6

Anisimova I (2014) Modern approaches to the construction of financial instruments at markets of electric energy. Czech Journal of Social Sciences, Business and Economics 3(1):64-73. doi: 10.24984/cjssbe.2014.3.1.8

Baburina NA, Tarkhanova EA, Fedorova OB (2017) Innovational approaches to attracting people savings in the modern economy. Marketing and Management of Innovations 3:187-197. doi: 10.21272/mmi.2017.3-18

Barth ME, Gomez-Biscarri J, Kasznik R, López-Espinosa G (2017) Bank earnings and regulatory capital management using available for sale securities. Review of Accounting Studies 22(4):1761-1792. doi: $10.1007 / \mathrm{s} 11142-017-9426-\mathrm{y}$

Central Bank of Russia (2016a) Analytics. http://www.cbr.ru/analytics/ Accessed 17 Jul 2018

Central Bank of Russia (2016b) Conditions for banking loans. http://www.cbr.ru/DKP/iubk/iubk_16-3.pdf Accessed 29 Aug 2018

Central Bank of Russia (2018) Financial and market data. http://www.cbr.ru/analytics/ Accessed 28 Aug 2018

Chamberlin G (2015) Coordinating Monetary and Fiscal Policies in the Open Economy. International Economics Letters 4(1):15-25. doi: 10.24984/iel.2015.4.1.2

Federal Statistics (2018) Statistical Compendium. http://gks.ru Accessed 28 Aug 2018

Gavurova B, Belas J, Kocisova K, Kliestik T (2017) Comparison of Selected Methods for Performance Evaluation of Czech and Slovak Commercial Banks. Journal of Business Economics and Management 18(5):852-876 doi:10.3846/16111699.2017.1371637

Jiroudková A, Rovná LA, Strielkowski W, Šlosarčík I (2015) EU Accession, Transition and Further Integration for the Countries of Central and Eastern Europe. Economics and Sociology 8(2):11-25. doi: 10.14254/2071789X.2015/8-2/1

Kovelin DM, Tarkhanova EA (2017) Razvitie rynka bankovskego kreditirovaia naselenia Rossii: otsenka, problemy i perspektivy [Development of bank credit market for Russian population: assessment, problems and perspectives]. Economika. Biznes. Banki 1(18):76-86.

Kunitsyna N, Britchenko I, Kunitsyn I (2018) Reputational risks, value of losses and financial sustainability of commercial banks. Entrepreneurship and Sustainability Issues 5(4):943-955. doi: 10.9770/jesi.2018.5.4(17)

Lavrushin IO (ed.) Rol' kredita i modernisatsia deyatelnosti bankov v sfere kreditovanya [The role of credit and modernisation of banking activity in the credit sphere], $1^{\text {st }}$ edn, (Knorus, Moscow, 2012), 272 p. 
Lukmanova IG, Mishlanova MY (2015) Determinant Analysis of Public-Private Partnership in Russia. International Journal of Economics and Financial Issues 5(3S):208-216.

Ministry of Economic Development of Russian Federation (2018) Economic statistics. http://economy.gov.ru/wps/wcm/connect/6199b307-3102-42ca-935c-19b05d2d398b/180704_econ_picture.pdf Accessed 22 Aug 2018

National Credit Bureau (2016) On credits. http://nbki.ru/company/news/?id=20401 Accessed 27 Aug 2018

National Credit Bureau (2017) Banks increase the issue of credit cards. https://www.nbki.ru/company/news/?id=20784 Accessed 27 Aug 2018

Paulík J, Kombo F, Ključnikov A (2015) CSR as a driver of satisfaction and loyalty in commercial banks in the Czech Republic. Journal of International Studies 8(3):112-127. doi: 10.14254/2071-8330.2015/8-3/9

RAMR (2018) Trends and perspectives of car credits. https://www.napinfo.ru/articles/trendy-i-perspektivyavtokreditovaniya Accessed $20 \mathrm{Jul} 2018$

RBK (2016) Number of credits. https://www.rbc.ru/money/28/01/2016/56a9005f9a7947055b77bd8f Accessed 29 Aug 2018

Rusanov Y, Rovensky AY, Belyanchikova T, Natocheeva NN, Sysoeva AA (2015) Social priorities of internal banking assortment (products) policy. European Research Studies Journal 18(4):307-320.

Simionescu M, Ciuiu D, Bilan Y, Strielkowski W (2016) GDP and Net Migration in Some Eastern and SouthEastern Countries of Europe. A Panel Data and Bayesian Approach. Montenegrin Journal of Economics 12(2):161175. doi: 10.14254/1800-5845.2016/12-1/10

Teresienè D (2018) Performance measurement issues in central banks. Entrepreneurship and Sustainability Issues 6(1):176-189. doi: 10.9770/jesi.2018.6.1(12)

Yusupova OA (2015) Foregone debts in credit portfolios of Russian banks, causes and methods of dealing with. Finances and Credit 3:14-16.

Zinkevich VA, Shtatov DN (2007) Information risks: analysis and quantitative assessment. Accounts Department and Banks 2:48-53. 